\title{
Effect that an educational program for cystic fibrosis patients and caregivers has on the contamination of home nebulizers*
}

\author{
Efeito de um programa de educação para cuidadores e pacientes com \\ fibrose cística na contaminação de nebulizadores de uso domiciliar
}

\author{
Adriana Della Zuana, Doroti de Oliveira Garcia, Regina Célia Turola Passos Juliani, \\ Luiz Vicente Ribeiro Ferreira da Silva Filho
}

\begin{abstract}
Objective: To describe the pathogens found in home nebulizers and in respiratory samples of cystic fibrosis (CF) patients, and to evaluate the effect that a standardized instruction regarding cleaning and disinfection of nebulizers has on the frequency of nebulizer contamination. Methods: We included 40 CF patients (22 males), all of whom used the same model of nebulizer. The median patient age was $11.2 \pm 3.74$ years. We collected samples from the nebulizer mouthpiece and cup, using a sterile swab moistened with sterile saline. Respiratory samples were collected by asking patients to expectorate into a sterile container or with oropharyngeal swabs after cough stimulation. Cultures were performed on selective media, and bacteria were identified by classical biochemical tests. Patients received oral and written instructions regarding the cleaning and disinfection of nebulizers. All determinations were repeated an average of two months later. Results: Contamination of the nebulizer (any part) was detected in 23 cases (57.5\%). The nebulizer mouthpiece and cup were found to be contaminated in $16(40.0 \%)$ and 19 (47.5\%), respectively. After the standardized instruction had been given, there was a significant decrease in the proportion of contaminated nebulizers (43.5\%). Conclusions: In our sample of CF patients, nebulizer contamination was common, indicating the need for improvement in patient practices regarding the cleaning and disinfection of their nebulizers. A one-time educational intervention could have a significant positive impact.
\end{abstract}

Keywords: Cystic fibrosis; Nebulizers and vaporizers; Disinfection.

\section{Resumo}

Objetivo: Descrever os patógenos encontrados nos nebulizadores de uso domiciliar e nas amostras de trato respiratório de pacientes com fibrose cística $(\mathrm{FC})$ e verificar o efeito de uma instrução padronizada de higiene e desinfecção de nebulizadores na contaminação dos mesmos. Métodos: Foram incluídos no estudo 40 pacientes com FC (22 do sexo masculino) que utilizavam um mesmo modelo de nebulizador. A mediana de idade foi de 11,2 $\pm 3,74$ anos. Amostras dos nebulizadores foram coletadas do bocal e do copo reservatório utilizando-se um swab estéril umedecido em solução salina estéril. As amostras de trato respiratório dos pacientes foram colhidas por expectoração em coletor estéril ou com swab de orofaringe após estímulo de tosse. As culturas foram realizadas em meios seletivos, e a identificação bacteriana foi feita através de provas bioquímicas clássicas. Instruções verbais e escritas sobre higiene e desinfecção dos nebulizadores foram ministradas. Todas as determinações foram repetidas dois meses após, em média. Resultados: A contaminação de alguma parte dos nebulizadores foi observada em 23 casos (57,5\%). A contaminação do bocal e do copo foi similar, em 16 $(40.0 \%)$ e 19 casos (47.5\%), respectivamente. Houve uma redução significativa da proporção de nebulizadores contaminados $(43,5 \%)$ após a instrução padronizada. Conclusões: Nesta amostra de pacientes com FC, a contaminação dos nebulizadores foi alta, o que indica a necessidade de melhoria nas práticas de higiene e desinfecção dos nebulizadores de pacientes com FC. Uma única intervenção educacional pode ter um impacto positivo significativo.

Descritores: Fibrose cística; Nebulizadores e vaporizadores; Desinfecção.

*Study carried out at the Professor Pedro de Alcântara Institute for Children, University of São Paulo School of Medicine Hospital das Clínicas, São Paulo, Brazil.

Correspondence to: Adriana Della Zuana. Rua Wanderley, 1295, apto. 41, Perdizes, CEP 05011-001, São Paulo, SP, Brasil.

Tel. 5511 3868-2731. Cel: 5511 99216-8891. E-mail: dellazuana@yahoo.com.br

Financial support: None.

Submitted: 20 November 2013. Accepted, after review: 6 February 2014. 


\section{Introduction}

Cystic fibrosis (CF) patients are highly susceptible to colonization by and lung infection with specific bacteria, and the establishment of a chronic bronchopulmonary infection is the leading cause of progressive lung injury. ${ }^{(1)}$ The increasingly frequent need for prescribing inhaled medications to these patients has led to greater use of home nebulizers. ${ }^{(2,3)}$ It is accepted that pathogens are commonly isolated from nebulizers, and there is a concern that nebulizer equipment may be a contributing source of bacterial infection into the lower airways of these patients. ${ }^{(2,4)}$

According to Rosenfeld et al., ${ }^{(5)}$ hospitals have developed strict protocols for sterilization of nebulizers. In contrast, there are no guidelines for cleaning home nebulizers or existing guidelines are not well established. ${ }^{(6,7)}$ Hutchinson et al. ${ }^{(8)}$ suggest that contamination of home nebulizers is common and that it may be due to the variety of maintenance practices. Vassal et al..$^{(9)}$ emphasize that, in the absence of cleaning, most nebulizers of CF patients are contaminated with a pathogenic flora.

The risk of contamination of home nebulizer equipment depends on various factors, such as the type of equipment used, including the material the nebulizer is made of; the efficiency of the cleaning and disinfection method recommended to patients; the microbiological quality of tap water (if used); and the quality of patient adherence to recommendations. ${ }^{(10)}$ In addition, Jakobsson et al. ${ }^{(11)}$ are convinced that oral and written instructions given to patients and their caregivers regarding nebulizer cleaning and disinfection practices are important for maintaining high levels of adherence to these practices.

In 2003, a consensus statement on the importance of infection control in CF developed by the Cystic Fibrosis Foundation (CFF) mentioned proper cleaning and disinfection of home nebulizers as one of the relevant principles. ${ }^{(12)}$ In addition, that study pointed out the need for continuing educational programs so that good levels of adherence can be achieved. ${ }^{(12)}$

The objective of the present study was to describe the pathogens found in home nebulizers of and in respiratory samples from CF patients, and to evaluate the effect that a standardized instruction regarding cleaning and disinfection of nebulizers has on the frequency of nebulizer contamination.

\section{Methods}

The study sample consisted of patients diagnosed with $\mathrm{CF}$, in accordance with international standards, ${ }^{(13)}$ who were being treated at the Pediatric Pulmonology Outpatient Clinic of the University of São Paulo School of Medicine Hospital das Clínicas Institute for Children, located in the city of São Paulo, Brazil. Patients were selected on the basis of the following inclusion criteria: using a PRONEB ${ }^{\circledast}$ nebulizer and compressor system (PARI Medical Holding GmbH, Starnberg, Germany) and indicating interest in participating in the study upon receiving a telephone call. During a routine hospital visit, the parents or legal guardians of the patients received information about the study and gave written informed consent.

At the study outset, patients were instructed to bring the entire nebulizer system for verification. There was no mention of it being an assessment of contamination. A questionnaire was administered to establish what home method for cleaning and disinfecting nebulizers had been used until then.

At the time, samples were collected from the nebulizer medicine cup and mouthpiece for microbiological culture, by swabbing of the inner surface of the nebulizer medicine cup and mouthpiece with a sterile swab moistened with sterile saline (rotating the swab ten times clockwise). ${ }^{(14)}$

In addition, sputum samples or oropharyngeal swabs were collected from patients for microbiological culture. Sputum was collected by asking patients to expectorate into a sterile container, and oropharyngeal swabs were collected by rubbing of the retropharynx and pharyngeal pillars with a sterile swab (BD Brasil, São Paulo, Brazil). The samples collected from the patients and from the nebulizers, all of which were properly identified, were placed into an insulated bag with ice packs and sent to the microbiology laboratory within a maximum of three hours.

Cultures were performed at the Bacteriology Laboratory of the Adolfo Lutz Institute, located in the city of São Paulo, Brazil. The sputum samples and the oropharyngeal samples were directly smeared onto selective media. The media used included chocolate Agar, MacConkey agar, and selective media for the Burkholderia cepacia complex (B. cepacia selective medium; 0xoid Ltd., Basingstoke, UK), Stenotrophomonas maltophilia, and Staphylococcus aureus-Baird-Parker agar 
and/or mannitol agar (0xoid)-and all cultures were incubated at $37^{\circ} \mathrm{C}$ for $16-72 \mathrm{~h}^{(15)}$

The gram-negative bacilli isolated were identified phenotypically by extensive conventional biochemical tests that are already part of the routine practice of the Adolfo Lutz Institute.

The adopted cleaning and disinfection instructions were adapted from the model recommended by the $\mathrm{CFF}^{(12)}$ and from the instructions provided by the manufacturer of the nebulizer system used by the patients. At the end of sample collection, each patient and/or guardian received oral and written instructions regarding a standardized cleaning and disinfection process to be used henceforth that consisted of the following steps:

1. Cleaning: after use, the nebulizer should be disassembled and its parts should be washed inside and outside with mild detergent and tap water (except for the hose and its adapter, which should remain connected to the compressor for two minutes or should be left with the two ends hanging down in order to dry) and should be rinsed with tap water.

2. Disinfection: place the disassembled parts into a container filled with water and let it boil for five minutes. If the parts are disinfected with boiling water, rinsing is not necessary. Do not boil the hose, its adapter, or the mask. Repeat this procedure once a day.

3. Drying: after the final rinse, let the water drain from the material and dry it preferably with paper towels or a clean cloth.

4. Storage: assemble all parts of the nebulizer and store it in a container used for that sole purpose.

Patients were asked to bring their nebulizer equipment again at the next medical visit, and additional samples were collected from the nebulizers and the patients. At the time, the questionnaire was readministered in order to determine adherence to the recommended standardized method.

The study project was approved by the ethics committees of the Institute for Children and the Adolfo Lutz Institute, as well as by the Research Ethics Committee of the University of São Paulo School of Medicine Hospital das Clínicas (Protocol no. 0067/08).
For the purposes of the statistical analysis, categorical variables are expressed as frequencies and confidence intervals, and continuous variables are expressed as means, standard deviations, medians, and maximum and minimum values. The association between positive cultures and the remaining categorical variables was investigated by Fisher's exact test or the chi-square test. The difference between the frequencies of nebulizer contamination before and after the cleaning instructions had been given was assessed by McNemar's test. To determine whether the time interval between the first and second assessments would affect the results, we used a generalized estimating equations statistical model with binomial distribution, ${ }^{(16)}$ considering the time interval between the two assessments as a covariate. The sample size was calculated to yield a power of $80 \%$ to detect a $50 \%$ decrease in the frequency of nebulizer contamination, considering that, according to data in the literature, ${ }^{(14)}$ the rate of nebulizer contamination would be approximately $65 \%$ before the application of the proposed technique. For all calculations, the level of significance was set at $<5 \%$. Statistical analyses were performed with PASW Statistics 18 (IBM Corp., Armonk, NY, USA).

The research project was funded entirely by the department and laboratories involved. Interviews and sample collection were performed at the Physical Therapy Outpatient Clinic of the Institute for Children by the principal researcher.

\section{Results}

We evaluated $40 \mathrm{CF}$ patients (22 males and 18 females) aged 5 to 18 years (median, 11.2 years). Among the 40 patients evaluated, all (100\%) were being treated with inhaled DNase (Pulmozyme ${ }^{\circledast}$; Roche, São Paulo, Brazil) and 16 (40\%) were receiving inhaled antibiotic concomitantly. The median time between the evaluations was 63 days (range, 3-203 days).

The colonization profile of the patients, which was obtained through analysis of medical records, showed a predominance of chronic colonization with S. aureus and Pseudomonas aeruginosa and a lower frequency of colonization with the $B$. cepacia complex and S. maltophilia (Figure 1).

The data obtained from the questionnaire administered to assess patient practices regarding the cleaning and disinfection of their nebulizers showed that, at the time of the first collection, 16 
patients (40\%) reported having already received instruction on such practices from a professional. Approximately $80 \%$ of the patients reported being aware of the importance of proper cleaning, but only $11(27.5 \%)$ considered their cleaning and disinfection practices satisfactory. Patient practices regarding the cleaning, disinfection, drying, and storage of their nebulizer equipment varied widely, and most were considered unsatisfactory; however, there was a marked change after the instructions had been given (Table 1).

Of the 80 respiratory secretion samples collected from the patients at the two assessments, 60 were sputum samples and 20 were oropharyngeal swabs. S. aureus predominated (in 68.75\%), followed by $P$. aeruginosa (in 43.75\%), the $B$. cepacia complex (in 3.75\%), and S. maltophilia (in 2.75\%).

Contamination of the nebulizer (any part) was detected in 23 cases (57.5\%), and contamination of the nebulizer mouthpiece and cup was detected in 16 and 19 cases, respectively (Table 2). After standardized instruction regarding the cleaning and disinfection of home nebulizers had been given, the number of contaminated nebulizer cases dropped to 10 (25\%), and the number of contaminated nebulizer mouthpiece cases and contaminated nebulizer cup cases dropped to 7 and 5, respectively (Figure 2).

The frequency of contamination decreased by $43.5 \%$, which is significant considering the total number of contaminated nebulizers and the various parts of the nebulizer. However, the time interval between the two assessments had no influence on this decrease in contamination.

The nebulizer sample cultures detected a wide variety of microorganisms, with predominant detection of unidentified gram-negative bacilli (n $=14$; Table 3 ). $\ln 4$ cases, the same microorganism was detected in the culture of the respiratory secretion sample from the patient and in the nebulizer (any part) sample culture. In 2 of those cases, the agent was identified as belonging to the genus Pseudomonas, and, in the other 2 , it was identified as belonging to the genus Staphylococcus. Genetic analysis of these isolates (DNA macrorestriction analysis followed by pulsedfield gel electrophoresis) showed that they were unrelated strains (data not shown).

\section{Discussion}

Most CF patients use nebulizers routinely, ${ }^{(2)}$ and, in the present study, the prevalence of contamination of home nebulizers was found to be quite significant (57.5\%), despite the fact that most patients reported being aware of the importance of nebulizer cleaning and disinfection practices. This indicates the need for improvement in these practices.

The nebulizer cleaning and disinfection methods reported by patients before the standardized instruction had been given were, in most cases, not in line with international recommendations ${ }^{(12)}$, and only $25 \%$ of patients boiled the nebulizer parts, which is recommended by the CFF as a disinfection method.

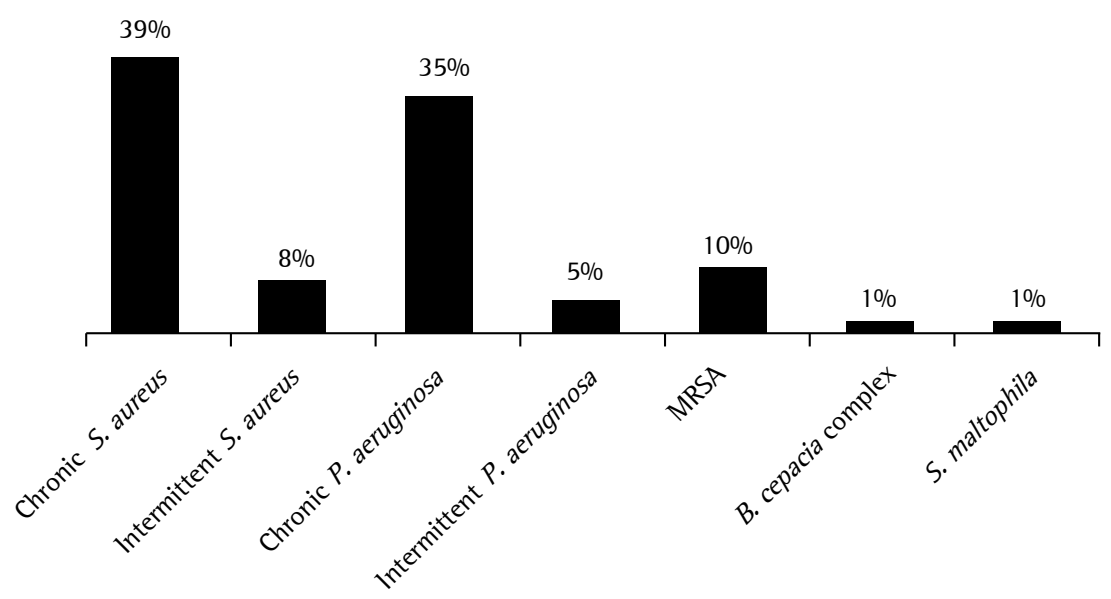

Figure 1 - Prior colonization of the patients included in the study $(\mathrm{n}=40)$. S. aureus. Staphylococcus aureus; P. aeruginosa: Pseudomonas aeruginosa; B. cepacia: Burkholderia cepacia; MRSA: methicillin-resistant $S$. aureus; and S. maltophilia: Stenotrophomonas maltophilia. 
Table 1 - Report of study participants' $(\mathrm{n}=40)$ practices regarding the cleaning, disinfection, drying, and storage of their home nebulizers at the two questionnaire administrations. ${ }^{a}$

\begin{tabular}{|c|c|c|}
\hline Question & $\begin{array}{c}\text { First } \\
\text { administration }\end{array}$ & $\begin{array}{c}\text { Second } \\
\text { administration }\end{array}$ \\
\hline You have been instructed on how to clean and disinfect your nebulizer & $16(40.0)$ & $40(100.0)$ \\
\hline \multicolumn{3}{|l|}{ The instruction was given by } \\
\hline A physician & $3(7.5)$ & $0(0.0)$ \\
\hline A nurse & $0(0.0)$ & $0(0.0)$ \\
\hline A physical therapist & $8(20.0)$ & $40(100.0)$ \\
\hline Others & $5(12.5)$ & $0(0.0)$ \\
\hline You are aware of the importance of proper cleaning & $32(80.0)$ & $38(95.0)$ \\
\hline \multicolumn{3}{|l|}{ You consider the way you clean your nebulizer equipment } \\
\hline Satisfactory & $11(27.5)$ & $36(90.0)$ \\
\hline Marginally satisfactory & $19(47.5)$ & $3(7.5)$ \\
\hline Unsatisfactory & $0(0.0)$ & $0(0.0)$ \\
\hline Do not know & $10(25.0)$ & $1(2.5)$ \\
\hline \multicolumn{3}{|l|}{ Number of uses per day } \\
\hline 1 & $27(67.5)$ & $29(72.5)$ \\
\hline 2 & $0(0.0)$ & $2(5.0)$ \\
\hline$>2$ & $13(32.5)$ & $9(22.5)$ \\
\hline \multicolumn{3}{|l|}{ Frequency of cleaning per week } \\
\hline 1 & $1(2.5)$ & $0(0.0)$ \\
\hline 2 & $3(7.5)$ & $0(0.0)$ \\
\hline 3 & $1(2.5)$ & $0(0.0)$ \\
\hline 7 & $10(25.0)$ & $1(2.5)$ \\
\hline After each inhalation & $22(55.0)$ & 39 (97.5) \\
\hline \multicolumn{3}{|l|}{ Parts that are cleaned } \\
\hline Сар & $40(100.0)$ & $40(100.0)$ \\
\hline Cup & $39(97.5)$ & $40(100.0)$ \\
\hline Mouthpiece & $40(100.0)$ & $40(100.0)$ \\
\hline Mask & $0(0.0)$ & $0(0.0)$ \\
\hline Inner supply tube & 39 (97.5) & $40(100.0)$ \\
\hline Hose & $29(72.5)$ & 31 (77.5) \\
\hline Compressor & $24(60.0)$ & $24(60.0)$ \\
\hline \multicolumn{3}{|l|}{ How you clean your nebulizer } \\
\hline Disassemble it into parts & $39(97.5)$ & $40(100.0)$ \\
\hline Scrubbing with your hands & $15(37.5)$ & $24(60.0)$ \\
\hline Scrubbing with a sponge & $17(42.5)$ & $14(35.0)$ \\
\hline Scrubbing with a cloth & $0(0.0)$ & $1(2.5)$ \\
\hline Detergent & 27 (67.6) & $40(100.0)$ \\
\hline Tap water & $33(82.5)$ & $40(100.0)$ \\
\hline Boiled water & $5(12.5)$ & $0(0.0)$ \\
\hline Rinsing & $32(80.0)$ & $40(100.0)$ \\
\hline \multicolumn{3}{|l|}{ How you disinfect your nebulizer } \\
\hline Alcohol & $3(7.5)$ & $1(2.5)$ \\
\hline Another product & $1(2.5)$ & $0(0.0)$ \\
\hline Soaking & $26(65.0)$ & $1(2.5)$ \\
\hline Rinsing with hot water & $8(20.0)$ & $1(2.5)$ \\
\hline Boiling of the parts & $10(25.0)$ & $38(95.0)$ \\
\hline \multicolumn{3}{|l|}{ How you dry your nebulizer } \\
\hline Natural air drying & $22(55.0)$ & $8(20.0)$ \\
\hline Paper towel & $8(20.0)$ & $22(55.0)$ \\
\hline Cloth & $10(25.0)$ & $10(25.0)$ \\
\hline \multicolumn{3}{|l|}{ How you store your nebulizer } \\
\hline Bag & 7 (17.5) & $8(20.0)$ \\
\hline Container & $20(50.0)$ & $31(77.5)$ \\
\hline No specific storage place & $13(32.5)$ & $1(2.5)$ \\
\hline
\end{tabular}

avalues expressed as $n(\%)$. 
Table 2 - Frequency of nebulizer contamination before and after the standardized instruction had been given $(\mathrm{n}=40)$.

\begin{tabular}{lcccc}
$\begin{array}{c}\text { Nebulizer } \\
\text { contamination }\end{array}$ & $\begin{array}{c}\text { Before the } \\
\text { instruction }\end{array}$ & $\begin{array}{c}\text { After the } \\
\text { instruction }\end{array}$ & $\mathrm{p}^{*}$ & $\begin{array}{c}\mathrm{p} \text { after correction by the } \\
\text { time interval between } \\
\text { assessments** }^{* *}\end{array}$ \\
\hline Any part & $23(57.5)$ & $10(25.0)$ & 0.002 & 0.001 \\
Mouthpiece & $16(40.0)$ & $7(17.5)$ & 0.022 & 0.011 \\
Cup & $19(47.5)$ & $5(12.5)$ & $<0.001$ & $<0.001$ \\
\hline
\end{tabular}

aValues expressed as $\mathrm{n}(\%) .{ }^{*}$ McNemar's test. ${ }^{* *}$ Generalized estimating equations model.

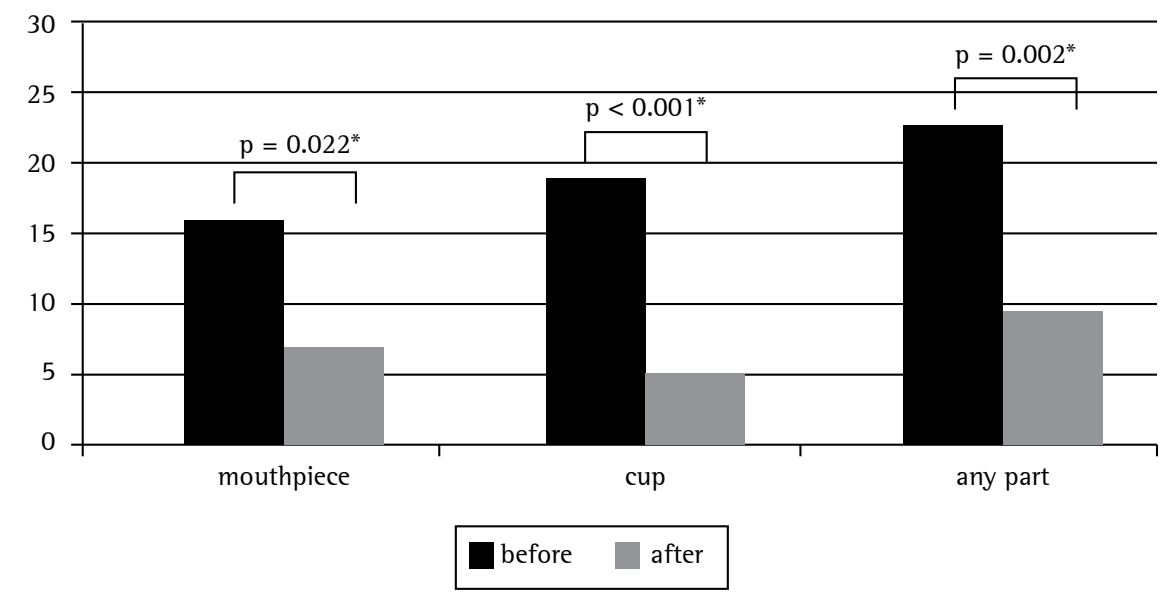

Figure 2 - Frequency of nebulizer contamination before and after the standardized instruction $(\mathrm{n}=40)$. *McNemar's test.

Table 3 - Frequency of identification of microorganisms in the cultures of samples collected from the various parts of the nebulizers before and after the standardized instruction had been given $(n=40)$.

\begin{tabular}{lcccc}
\hline & \multicolumn{2}{c}{ Before the instruction } & After the instruction \\
\cline { 2 - 4 } & Mouthpiece & Cup & Mouthpiece & Cup \\
\hline Non-fermenting gram-negative bacilli & 2 & 8 & 1 & 3 \\
Coagulase-negative Staphylococcus sp. & 6 & 2 & 3 & 2 \\
Acinetobacter sp. & 2 & 3 & 3 & 2 \\
Yeasts & 8 & 4 & 0 & 0 \\
Pseudomonas putida & 1 & 6 & 0 & 0 \\
Enterobacter spp. & 1 & 3 & 0 & 1 \\
Enterobacteria spp. & 2 & 3 & 0 & 0 \\
Klebsiella sp. & 0 & 2 & 1 & 1 \\
Stenotrophomonas maltophilia & 1 & 1 & 0 & 1 \\
Gram-positive bacilli & 1 & 2 & 0 & 0 \\
Burkolderia cepacia complex & 1 & 1 & 0 & 1 \\
P. fluorescens & 1 & 2 & 0 & 0 \\
P. aeruginosa & 1 & 2 & 0 & 0 \\
Escherichia coli & 0 & 1 & 1 & 0 \\
S. aureus & 1 & 0 & 1 & 0 \\
Achromobacter xylosoxidans & 0 & 1 & 0 & 0 \\
\hline
\end{tabular}

Patients having received one-time standardized oral and written instructions resulted in a $43.5 \%$ decrease in contamination within an average of two months between the two assessments, which shows the potential of educational interventions in such a scenario. 
Vassal et al. ${ }^{(9)}$ conducted a study in which 44 patients had chronic colonization with $P$. aeruginosa, 30 of whom (68\%) had a nebulizer that had been contaminated with bacteria immediately after drug nebulization and did not receive any cleaning. Comparatively, the rate of nebulizer contamination found in the present study was 57.5\%. Likewise, Blau et al., ${ }^{(14)}$ in a study on bacterial contamination of nebulizers in the home treatment of CF patients, evaluated 29 nebulizer systems and found contamination in $19(65 \%), P$. aeruginosa being identified in $10(35 \%)$. In contrast, in a study conducted in Brazil by Brzezinski et al., ${ }^{(3)}$ only 6 (21\%) of 28 nebulizers evaluated were contaminated with bacteria related to CF. The main difference between that study and ours is that, in the former, sample collection occurred at home visits, and it is of note that the samples were left at room temperature before being taken for analysis. ${ }^{(3)}$

Although in the present study we found a relatively small proportion of microorganisms typical of CF in the nebulizer sample cultures, a significant proportion of these cultures $(n=14)$ were found to be positive for non-fermenting gram-negative bacilli, which were not characterized phenotypically. These microorganisms can be pathogenic to CF patients, since there are relatively frequent reports of errors in microbiological identification. ${ }^{(17,18)}$

Rosenfeld et al. ${ }^{(7)}$ reported that the home nebulizer sample cultures from CF patients were frequently positive for S. aureus (55\%), $P$. aeruginosa (35\%), and species of the genus Klebsiella (19\%). However, the concordance between sputum cultures and nebulizer sample cultures was poor. When studying 35 home nebulizers, Hutchinson et al. ${ }^{(8)}$ found that 3 were contaminated with the $B$. cepacia complex and 4 were contaminated with $S$. maltophilia. Although 34 patients had $P$. aeruginosa in their sputum, none of the nebulizers were positive for this microorganism. In addition, those authors reported that, even after cleaning, 69\% of the nebulizers were contaminated with various types of gram-negative bacteria.

Blau et al. ${ }^{(14)}$ stated that the manufacturer's instructions provided with PARI Medical Holding $\mathrm{GmbH}$ nebulizer systems were inadequate, since they still recommended soaking the nebulizer in a solution of water and acetic acid for disinfection, which does not ensure disinfection against $S$. aureus or B. cepacia. ${ }^{(2)}$ Instructions currently available on that manufacturer's website have been updated in accordance with the CFF recommendations. ${ }^{(19)}$ In addition, Reychler et al. ${ }^{(2)}$ reported no benefits of drying; however, they recognize that this recommendation should be taken into account because pathogens such as $P$. aeruginosa and B. cepacia are hydrophilic, and drying should be a step in the cleaning process. The consensus statement published by the $\mathrm{CFF}^{(12)}$ states that the practices regarding the cleaning, disinfection, and drying of nebulizer parts are key steps for infection control in CF patients, both at home and in the hospital setting. However, data from questionnaires administered to CF patients regarding their home nebulizer cleaning and disinfection routine show a wide variety of cleaning practices. ${ }^{(20)}$ At our facility, the recommendations regarding the cleaning and disinfection of nebulizers used to be made in an empirical (non-standardized) way; after the results of the present study were made known, the CFF recommendations were adopted. This one-time educational intervention delivered orally and in writing by the same professional resulted in a significant decrease in contamination of the nebulizer equipment, despite the varying time interval between assessments.

The development of recommendations, such as those by the CFF, is only the first step in infection control; it is necessary to disseminate information and educate patients and their caregivers about cleaning and disinfection practices, since there may be cultural and social barriers to their implementation. ${ }^{(21,22)}$ In addition, education about these practices should be offered to undergraduate physical therapists and to all professionals who prescribe inhaled medications. (4) Although various authors have recommended the use of oral and written instructions regarding these practices, ${ }^{(10,11,14)}$ our study unequivocally demonstrates the impact of this type of approach over an average two-month period of reassessment. However, among the limitations of the present study are the lack of a control group and the lack of subsequent sample collections to assess changes in the contamination profile of the nebulizer equipment, since it is possible that adherence to the recommended practices would decrease over time. Regarding the lack of a control group, we consider this to be an appropriate measure to minimize patient exposure to the 
theoretical risk of continuing to use contaminated nebulizer equipment, without being provided with correct instructions on how to clean and disinfect it at the first interview. Regarding the possibility of loss of effect, another assessment of contamination of the nebulizer equipment of the same patients would answer this query.

Future directions for studies in this area include determining more effective ways to promote adherence to infection control practices and developing mechanisms to assess the clinical impact of these practices on the basis of the results obtained with patients.

\section{Acknowledgments}

We would like to thank Professor Ulysses Dória Filho for his assistance with the sample size calculation and preliminary statistical analyses and statistician Ângela Tavares Paes for her assistance with the statistical model. We would also like to thank the patients and their parents for their commitment to participate in the study.

\section{References}

1. Gibson RL, Burns JL, Ramsey BW. Pathophysiology and management of pulmonary infections in cystic fibrosis. Am J Respir Crit Care Med. 2003;168(8):918-51. http:// dx.doi.org/10.1164/rccm.200304-505S0

2. Reychler G, Aarab K, Van Ossel C, Gigi J, Simon A, Leal T, et al. In vitro evaluation of efficacy of 5 methods of disinfection on mouthpieces and facemasks contaminated by strains of cystic fibrosis patients. J Cyst Fibros. 2005;4(3):183-7. http://dx.doi.org/10.1016/j. jcf.2005.06.001

3. Brzezinski LXC, Riedi CA, Kussek P, Souza HH, Rosário N. Nebulizers in cystic fibrosis: a source of bacterial contamination in cystic fibrosis patients? J Bras Pneumol. 2011;37(3):341-7. http://dx.doi.org/10.1590/ S1806-37132011000300010

4. Lester MK, Flume PA, Gray SL, Anderson D, Bowman CM. Nebulizer use and maintenance by cystic fibrosis patients: a survey study. Respir Care. 2004;49(12):1504-8.

5. Rosenfeld M, Emerson J, Astley S, Joy P, Williams-Warren J, Standaert TA, et al. Home nebulizer use among patients with cystic fibrosis. J Pediatr. 1998;132(1):125-31. http:// dx.doi.org/10.1016/S0022-3476(98)70497-4

6. O'Malley CA, VandenBranden SL, Zheng XT, Polito AM, McColley SA. A day in the life of a nebulizer: surveillance for bacterial growth in nebulizer equipment of children with cystic fibrosis in the hospital setting. Respir Care. 2007;52(3):258-62.

7. Rosenfeld M, Joy P, Nguyen CD, Krzewinski J, Burns JL. Cleaning home nebulizers used by patients with cystic fibrosis: is rinsing with tap water enough? J Hosp Infect. 2001;49(3):229-30. http://dx.doi.org/10.1053/ jhin.2001.1083

8. Hutchinson GR, Parker S, Pryor JA, Duncan-Skingle F, Hoffman PN, Hodson ME, et al. Home-use nebulizers: a potential primary source of Burkholderia cepacia and other colistin-resistant, gram-negative bacteria in patients with cystic fibrosis. J Clin Microbiol. 1996;34(3):584-7.

9. Vassal S, Taamma R, Marty N, Sardet A, d'athis P, Brémont F, et al. Microbiologic contamination study of nebulizers after aerosol therapy in patients with cystic fibrosis. Am J Infect Control. 2000;28(5):347-51. http://dx.doi. org/10.1067/mic.2000.110214

10. Jakobsson BM, Onnered AB, Hjelte L, Nystrom B. Low bacterial contamination of nebulizers in home treatment of cystic fibrosis patients. J Hosp Infect. 1997;36(3):201-7. http://dx.doi.org/10.1016/S0195-6701(97)90195-X

11. Jakobsson B, Hjelte L, Nyström B. Low level of bacterial contamination of mist tents used in home treatment of cystic fibrosis patients. J Hosp Infect. 2000;44(1):37-41. http://dx.doi.org/10.1053/jhin.1999.0658

12. Saiman L, Siegel J; Cystic Fibrosis Foundation. Infection control recommendations for patients with cystic fibrosis: microbiology, important pathogens, and infection control practices to prevent patient-to-patient transmission. Infect Control Hosp Epidemiol. 2003;24(5 Suppl):S6-52. http://dx.doi.org/10.1086/503485

13. Farrell PM, Rosenstein BJ, White TB, Accurso FJ, Castellani C, Cutting GR, et al. Guidelines for diagnosis of cystic fibrosis in newborns through older adults: Cystic Fibrosis Foundation consensus report. J Pediatr. 2008;153(2):S4S14. http://dx.doi.org/10.1016/j.jpeds.2008.05.005

14. Blau H, Mussaffi H, Zahav MM, Prais D, Livne M, Czitron BM, et al. Microbial contamination of nebulizers in the home treatment of cystic fibrosis. Child Care Health Dev. 2007;33(4):491-5. http://dx.doi. org/10.1111/j.1365-2214.2006.00669.x

15. da Silva Filho LV, Levi JE, Bento CN, Rodrigues JC, da Silvo Ramos SR. Molecular epidemiology of Pseudomonas aeruginosa infections in a cystic fibrosis outpatient clinic. J Med Microbiol. 2001;50(3):261-7.

16. Zeger SL, Liang KY. Longitudinal data analysis for discrete and continuous outcomes. Biometrics. 1986;42(1):12130. http://dx.doi.org/10.2307/2531248

17. McMenamin JD, Zaccone TM, Coenye T, Vandamme P, LiPuma JJ. Misidentification of Burkholderia cepacia in US cystic fibrosis treatment centers: an analysis of 1,051 recent sputum isolates. Chest. 2000;117(6):1661-5. http://dx.doi.org/10.1378/chest.117.6.1661

18. Brisse S, Cordevant C, Vandamme P, Bidet P, Loukil C, Chabanon G, et al. Species distribution and ribotype diversity of Burkholderia cepacia complex isolates from French patients with cystic fibrosis. J Clin Microbiol. 2004;42(10):4824-7. http://dx.doi.org/10.1128/ JCM.42.10.4824-4827.2004

19. PARI [homepage on the Internet]. Starnberg: PARI; c20082013 [cited 2013 Nov 20]. Cleaning \&t Maintenance; [about 2 screens]. Available from:. http://www.pari.com/ education_ceu/cleaning_maintenance.html

20. Pitchford KC, Corey M, Highsmith AK, Perlman R, Bannatyne R, Gold R, et al. Pseudomonas species contamination of cystic fibrosis patients' home inhalation equipment. J Pediatr. 1987;111(2):212-6. http://dx.doi. org/10.1016/S0022-3476(87)80069-0

21. Garber E, Desai M, Zhou J, Alba L, Angst D, Cabana M, et al. Barriers to adherence to cystic fibrosis infection control guidelines. Pediatr Pulmonol. 2008;43(9):900-7. http://dx.doi.org/10.1002/ppul.20876

22. Miroballi Y, Garber E, Jia HM, Zhou JJ, Alba L, Quittell $\mathrm{LM}$, et al. Infection control knowledge, attitudes, and practices among cystic fibrosis patients and their families. Pediatr Pulmonol. 2012;47(2):144-52. http://dx.doi. org/10.1002/ppul.21528 


\section{About the authors}

Adriana Della Zuana

Master's Student. Graduate Program in Health Sciences, University of São Paulo School of Medicine, São Paulo, Brazil.

Doroti de Oliveira Garcia

Level V1 Researcher. Bacteriology Center, Adolfo Lutz Institute, São Paulo, Brazil.

Regina Célia Turola Passos Juliani

Supervisor. Hospital Division, Physical Therapy Section, Professor Pedro de Alcântara Institute for Children, University of São Paulo School of Medicine Hospital das Clínicas, São Paulo, Brazil.

Luiz Vicente Ribeiro Ferreira da Silva Filho

Attending Physician. Department of Pulmonology, Professor Pedro de Alcântara Institute for Children, University of São Paulo School of Medicine Hospital das Clínicas, São Paulo, Brazil. 